\title{
Presión e intereses en torno al cargo de protector general de indios del Nuevo Reino de León: el caso de Nicolás de Villalobos, 1714-1734/
}

\author{
Pressure and interests about the office \\ of the Nuevo Reino de León Indians protector: \\ the case of Nicolás de Villalobos, 1714-1734
}

Ascensión Baeza Martín

Universidad de Sevilla

La perniciosa transformación sufrida por el sistema de utilización de la mano de obra indígena en el Nuevo Reino de León, caracterizado por los estragos y esclavitud a los indios en las encomiendas o congregas, provocaban su rebeldía. Los frecuentes asaltos a los colonos españoles y sus propiedades, así como las expediciones y castigos de estos contra los aborígenes reflejaban las duras condiciones de vida en esa provincia del nordeste del Virreinato de Nueva España y el constante estado de guerra de la misma. Con los substanciales cambios implantados desde el gobierno virreinal mediante el envío en $1714 \mathrm{del}$ comisionado Francisco de Barbadillo Victoria y la creación por éste del cargo de protector general de indios en esa tierra, se trató de frenar esta incontrolable situación. La dificultad de que se afianzara la figura del protector, tan necesaria en los primeros tiempos de las reformas, dejaría ver los partidismos, pasiones e intereses de las autoridades y de los diversos sectores sociales de esa región fronteriza.

Palabras Clave: Nuevo León; Esclavitud; Congregas; Frontera; Colonos, Estado de guerra; Francisco de Barbadillo Victoria; Protector de indios; Nicolás de Villalobos; Reformas; Partidismos.

The pernicious transformation undergone by the system of use of the indigenous workpeople in the Nuevo Reino de Leon, characterized by the ravages and slavery to the Indians in the encomiendas or congregas, provoked their rebelliousness. The frequent assaults to the Spanish colonists and their properties, as well as the expeditions and punishments of these against the natives reflected the hard conditions of life in that province of the northeast of the Viceroyalty of Nueva España and the constant been military of the same one. With the substantial changes implanted from the viceregal government by means of the shipment in 1714 of the commissioner Francisco de Barbadillo Victoria and the creation by this one of the employment of General Indians Protector in that earth, one was to restrain this uncontrollable situation. The difficulty of which the figure of the protector, so necessary in the first times of the reforms, held fast, would let see the partisanship, passions and interests of the authorities and the diverse social sectors of that border region.

Keywords: Nuevo Leon; Slavery; Congregas; Frontier; Colonist; Been military; Francisco de Barbadillo Victoria, Indians' Protector; Nicolas de Villalobos; Reforms; Partisanships. 
A raíz del descubrimiento y conquista del Nuevo Mundo y para defender a los indios de los abusos y agravios de los españoles, la Corona mandó promulgar — como es sabido — una serie de disposiciones relativas a su libertad y buen tratamiento. Junto con otras dirigidas a afianzarlos como vasallos del soberano español e incluirlos en el sistema jurídico colonial, formarían parte del Cedulario Indiano reunido por Diego de Encinas (1596) y, más tarde, de la Recopilación de Leyes de los Reinos de Indias (1680). Muchos de esos preceptos tuvieron que ser reiteradamente recordados a lo largo del periodo de dominación por su frecuente inobservancia. ${ }^{1}$

De entre las providencias que se prescribieron una fue la de instituir en Perú y Nueva España en 1528 el cargo de protector general de indios, recayendo el primer nombramiento, en el caso del Virreinato novohispano, en fray Juan de Zumárraga, obispo electo de México. En 1582 fue suprimido, restableciéndose en 1589. Este empleo, que sería abolido o volvería a implantarse en diversas épocas y zonas, estuvo en manos del clero secular o regular, de obispos, de fiscales de Audiencias, etc., llegando a fundarse en 1592 el Juzgado General de Indios de Nueva España regulado por unas ordenanzas. ${ }^{2}$

Al igual que en otras áreas, en el Nuevo Reino de León, situado en la frontera nordeste del territorio novohispano, los gobernadores, las justicias y otros cargos públicos tenían el deber de informar acerca del trato a los indígenas. Los españoles, ya como encomenderos y después como capitanes protectores, estaban llamados a ser los defensores de aquellos indios que recibían en encomienda como fuerza de trabajo y a los que se compro-

1 Diego de Encinas (recop.): Leyes de Indias. Cedulario de Encinas. Estudio e índices por Alfonso García Gallo. Madrid, Cultura Hispánica, 1990. Francisco de Icaza Dufour (coord.): Recopilación de Leyes de los Reynos de las Indias. México, Miguel Ángel Porrúa, 1987, 5 vols.

2 Paulino Castañeda Delgado: "La condición miserable del indio y sus privilegios", Anuario de Estudios Americanos (AEA), XXVIII, Sevilla, 1971, pp. 245-335, pp. 276-277. Se citan las reales cédulas (Burgos, 15 de febrero de 1528 y Lisboa, 27 de mayo de 1582) en donde constaban las razones por las que se creo y suprimió dicho cargo. Constantino Bayle (SJ): "El protector de indios", AEA, II, Sevilla, 1945, pp. 1-180, pp. 25-114. Woodrow Borah: El Juzgado General de Indios de la Nueva España. México, Fondo de Cultura Económica (FCE), 1985, pp. 104-109. Estudios sobre la figura del protector de indios en distintas franjas del borde septentrional de ese Virreinato en Philip Wayne Powell: Capitán mestizo. Miguel Caldera y la frontera norteña. La pacificación de los chichimecas (1548-1597). México, FCE, 1980. Charles R. Cutter: The Protector de Indios in colonial New Mexico, 1659-1821. Alburquerque, University of New México Press, 1986. Beatriz Suñe Blanco: "Evolución de la figura del protector de indios en la frontera norte de Nueva España”, en Antonio Gutiérrez Escudero y María Luisa Laviana Cuetos (coords.): Estudios sobre América, siglos XVI-XX. Sevilla, Asociación Española de Americanistas, 2005, pp. 727-744. 
metían a adoctrinar, alimentar y a cumplir con ellos las demás obligaciones inherentes a esta concesión que no era una propiedad.

Sin embargo, el funcionamiento de la encomienda en esta provincia difería del practicado en el México central o meridional por diversas causas, entre ellas, por las abundantes tribus apenas pobladas y su nomadismo o la exigua ventaja económica de la misma. Estas y otras características, unidas a la tolerancia de las autoridades y lejanía del gobierno virreinal, darían lugar a que dicha institución se transformara y corrompiera, resultando una formación mixta denominada más tarde congrega. Esto ocurriría pese a que en 1672 se había expedido una real cédula ordenando que a los indios que se redujeran pacíficamente en esa región se les congregara en pueblos, repartiera tierras y eximiera de tributar durante diez años, prohibiendo bajo graves penas que se les vendiera, esclavizara, o traspasara, como se había hecho hasta entonces. Sólo se cambió el nombre de encomienda por el de congrega, siendo ésta para los dueños, como expresaría posteriormente el virrey duque de Linares, "un honesto título de dominarlos tiránicamente sin cumplir con el fin para que se les aplican, que es el de que los domestiquen y eduquen." ${ }^{3}$

Tampoco tuvo efecto un nuevo despacho cursado años después por informe del obispo de Guadalajara (Nueva Galicia) Juan de Santiago de León Garabito tras su visita pastoral a esas tierras ni las censuras de otro de sus obispos, Diego Camacho de Ávila. ${ }^{4}$

Los abusos, la tradición esclavista iniciada desde tiempos del primer gobernador Luís Carvajal de la Cueva y sus colaboradores, la desestructu-

3 Archivo General de Indias (AGI), Guadalajara, 166. Real cédula de la reina gobernadora. Madrid, 9 de mayo de 1672 y Linares al rey. México, 20 de septiembre de 1715. Cita la cédula, entre otros, Silvio Zavala: Entradas, congregas y encomiendas de indios en el Nuevo Reino de León. Sevilla, Universidad de Sevilla, 1992, pp. 90-91. Andrés Montemayor Hernández: "La congrega o encomienda en el Nuevo Reino de León”, Humanitas, 11. Monterrey (México), 1970, pp. 539-575, pp. 546-547 y 563. Más datos del tema y otros de esa región en Alonso de León: Historia de Nuevo León con noticias sobre Coahuila, Tejas y Nuevo México. México, Librería de la Vda. de Ch. Bouret, 1909. Eugenio del Hoyo: Historia del Nuevo Reino de León (1577-1723). Monterrey, Instituto Tecnológico y de Estudios Superiores, 1972, 2 vols. Juan Bautista Chapa: Historia del Nuevo Reino de León de 1650 a 1690. Monterrey, Gobierno del Estado de Nuevo León, 1990.

4 AGI, Guadalajara, 166. Gerónimo López Prieto (SJ) a Juan de Oliván. Colegio de San Javier de Monterrey, 2 de enero de 1714. Refiere que la real cédula llegó cuando ya había fallecido el obispo. Ibidem. Francisco de Barbadillo Vitoria al virrey. México, 23 de marzo de 1716. Carlos Manuel Valdés: La gente del mezquite. Los nómadas del noreste en la colonia. México, Centro de Investigaciones y Estudios Superiores en Antropología Social, 1995, p. 188. Da noticias de la visita del obispo tomada de otras fuentes y analiza interesantes aspectos de la vida cotidiana y evolución de las tribus indígenas de la frontera nororiental en contraste con los de otros grupos de ese Virreinato. Montemayor, "La congrega", p. 564. 
ración de sus núcleos familiares, amen de otras estrategias utilizadas por los españoles en su avance colonizador en detrimento de los indígenas, de su espacio y recursos habituales, fueron provocando su huida y rebeldía, volviendo a sus antiguos refugios y ritos. En su desquite y confederados con los indios gentiles que se resistieron a ser dominados, cometían a menudo asaltos, muertes y demás barbaries contra la población. Tierra de "guerra viva" se la consideró, al igual que otras del septentrión novohispano de similares características. ${ }^{5}$

Esencialmente lo mismo sucedía en esa región a inicios del siglo XVIII, como se prueba por un informe mandado realizar hacia 1713 por el oidor de la Audiencia de Guadalajara, Juan de Oliván Rebolledo, acerca del tratamiento que se les daba a los indígenas en las congregas. En síntesis, se reconoce que los indios se obtenían "a fuerza de armas y miedos" mediante entradas a sus tierras con licencias que pagaban al gobernador, para después congregarlos en sus haciendas donde solían permanecer sólo durante la cosecha; que por su labor, que duraba desde el amanecer hasta que oscurecía, se les daba usualmente una exigua ración de maíz al día y unas prendas de vestir; que, aunque no con el descaro del pasado, se seguía practicando la compraventa de indios adultos o párvulos, que arrebataban a sus madres, así como su alquiler y trueque; que salvo rara excepción, ni les enseñaban la doctrina ni los llevaban a las parroquias a aprenderla, consintiéndoles, en algunos casos, conductas inmorales para contentarlos y no perder su servicio.

Algunos encomenderos se justificaban diciendo que eran mayores las sumas que desembolsaban que el beneficio obtenido con los indios, pues, por la licencia para la entrada pagaban 25, 30 ó 40 pesos, por la visita del gobernador $50 \mathrm{y}$ al escribano 100 por un título o traspaso de encomienda o congrega, sin quedarle recurso para pedir justicia debido a su pobreza y a las 200 leguas que les separaban de la Audiencia de Nueva Galicia. ${ }^{6}$

5 Dos notables y vastos estudios sobre los procesos históricos, etnias y otras materias del Septentrión novohispano en su conjunto: Luis Navarro García: Don José de Gálvez y la Comandancia General de las Provincias Internas del Norte de Nueva España. Sevilla, EEHA, 1964 y Alfredo Jiménez Núñez: El gran norte de México. Una frontera imperial en la Nueva España (1540-1820). Madrid, Tebar, 2006.

6 AGI, Guadalajara, 166. Oliván al rey. Guadalajara, 20 de marzo y 27 de julio de 1714. Recogía una información proporcionada por el vicario y juez eclesiástico de Monterrey, Gerónimo López Prieto, quien, a instancias de Oliván, le había remitido un testimonio de autos. AGI, Guadalajara, 92. Declaraciones de los capitanes Simón de Jáuregui y Francisco Antonio de Avia. Monterrey, 29 de diciembre de 1713 y 2 de enero de 1714, en Autos sobre el tratamiento a los indios ("Autos"), fs. 1v.-3v. y 8-8v. Sus declaraciones coinciden con las del resto de testigos, todos muy conocedores de lo que ocurría en esa región. Ibidem. Certificación del presbítero Juan de Arellano. Monterrey, 2 de enero de 1714, fs. 11-13. 
Los indígenas, como ya referimos, vengaban las tiranías con hostilidades a los vecinos. El virrey Linares las atribuía a "su veleidad y barbarismo" pero, también, a "no haber quien trabaje en amansarlos y sobrar quien los maltrate y despeche". Al fiscal del Consejo de Indias le causaría asombro comprobar cómo, estando esa provincia subordinada al superior gobierno del virrey, no se hubiera puesto ya remedio. Juzgaba que lo orientado a la mayor libertad de los indios y a su adoctrinamiento se estaba perdiendo por "la insaciable y asquerosa codicia y interés" de unos particulares. El Consejo, en febrero de 1715, subrayó la urgencia de aplicar medidas proponiendo que se enviara a Oliván a que pusiera en práctica la real cédula de 1672 y procediese contra los culpados.

Parece que al Consejo no le habían llegado aún noticias de que desde diciembre de 1714 ya estaba cumpliendo esa y otras tareas a través de una comisión el alcalde de Corte de la Audiencia de México Francisco de Barbadillo Victoria.?

\section{Creación del cargo de protector en tierras neoleonesas}

La instauración del empleo de protector de indios en Nuevo León estuvo vinculada con la labor que a Barbadillo se le encomendó ejecutar en ese lugar. La gestión había sido planificada y aprobada en Junta general de Guerra y Hacienda celebrada el 22 de agosto de 1714, bajo la presidencia del virrey Linares. En ella se trataron varios y graves asuntos pendientes referidos a la delicada y ruinosa situación que se vivía en ese territorio, que, según auguraban algunos con tintes melodramáticos, hacía presagiar su ocaso. ${ }^{8}$

A este fin ya se habían formalizado una serie de denuncias, entre ellas la del que fuera gobernador de esa región, Francisco de Mier y Torres; de los capitulares del Ayuntamiento de Monterrey, su capital; del franciscano fray Juan de Losada; del jesuita Gerónimo López Prieto o del ya citado oidor Oliván, proponiendo estos últimos como recurso la creación de un

7 AGI, Guadalajara, 166. Linares al rey. México, 20 de septiembre de 1715. AGI, Guadalajara, 92. Respuesta del fiscal del Consejo. Madrid, 8 de febrero de 1715 y Consejo, 11 de febrero de 1715 .

8 AGI, Guadalajara, 166. Certificación de Pedro de Luna y Gorráez. México, 7 de septiembre de 1714. Da fe de la celebración de la Junta, de lo que en ella se trató y del nombramiento de Barbadillo. 
Obispado, la extinción de las congregas y formación de pueblos de indios a los que se les pagaría un jornal cuando fuesen requeridos para trabajar fuera.

Haciendo sólo un breve apunte de la Junta, de la comisión y sus resultados, diremos que las materias a debatir fueron cuatro. Dos referidas a la situación de los indios y medidas a tomar, ya descritas, y el resto con las tácticas a seguir para combatir sus ataques. Ataques que se habían agravado de cinco años a esa parte con un balance de más de 300 vecinos muertos, sobre todo pastores y sus parientes, y el robo de unas 40.000 ovejas y a cuyo efecto se pretendía formar una compañía volante y fundar una villa (San Felipe de Linares) como protección contra los indios gentiles de la sierra de Tamaulipas.

En la Junta se aprobó la propuesta del fiscal de la Audiencia de enviar un ministro togado, eligiéndose a Barbadillo, quien a partir de diciembre de 1714 comenzaría la visita. No pudo empezarla antes por haber intentado impedirla, al parecer, el marqués de Villapuente y sus parciales residentes en México, pero con intereses en Nuevo León, pretextando razones aparentemente útiles al real servicio que al final se desestimaron. De acuerdo con las instrucciones que se le facilitaron y con su visión del estado de ese territorio, Barbadillo extinguió las congregas; procuró atraerse con indultos a los indígenas alzados; fundó tres pueblos de indios y repobló dos, con un total de unos 4.500, en los que dejó un misionero franciscano en cada uno, no sin dificultades, pues las medidas expropiatorias de tierras practicadas provocarían el descontento de algunos vecinos. Elaboró unas ordenanzas para el buen régimen y solidez de los pueblos fundados, en uno de cuyos capítulos se recogía la creación del empleo de protector general de indios para defensa y respaldo de todas las tribus indígenas pacificadas de esa región. El protector estaría supeditado al virrey, a quien daría cuenta de la actuación del gobernador con los indios, los cuales quedaban inhibidos de la jurisdicción de éste y de las demás justicias.

El visitador culminó su labor, que duró hasta marzo de 1716, con la formación de una compañía volante compuesta por 70 soldados, un capitán y un pagador. Su sostenimiento - 22.000 pesos anuales - se prorratearía entre los dueños de las estancias y haciendas de ovejas que entraban a pastar en ese lugar por ser los más beneficiados con ella.

No obstante, el gobernador de ese momento, Francisco Báez Treviño, no admitió al protector ni a las ordenanzas. Sólo lo haría si se lo mandaba 
el virrey. Barbadillo le intimó a cumplirlas, so pena de 2.000 pesos y a que correría de su cuenta y riesgo cualquier alteración que hubiera en los pueblos. Discurría que Treviño era reacio a aceptarlas por ser nativo de esa tierra, con muchos parientes y compadres y sin más miras que su provecho. Quizás, argumentaba, estuviese quejoso por haber extinguido las congregas, ya que él tenía una y con la nueva planta se le privaba de las utilidades que le brindaba.

Tampoco confiaba en la permanencia de las fundaciones y las otras medidas que había puesto en vigor, pese a haber hecho "la vista gorda" en algunas materias. Pensaba que era tanta la ofuscación de la gente de esa zona, que no les sería tan doloroso que les quitara a sus hijos como el que a los indios los hubiera puesto en pueblos. Temía que se frustrara su obra si tenía en cuenta la naturaleza de éstos, "extraña e irregular, la de los españoles, malvada y inicua; corta la aplicación al bien de estos indios y caridad con que se deben mirar". No le faltaba razón. De vuelta a México, le habían llegado noticias de la creciente oposición de los españoles contra los indígenas y sus nuevas poblaciones. Pocos años después se le designaría gobernador de esas tierras fronterizas. ${ }^{9}$

\section{José de Urrutia}

Barbadillo había nombrado como protector general de indios de las fronteras de Nuevo León a José de Urrutia, señalándole un sueldo de 700 pesos anuales sobre las Cajas de San Luís Potosí. Aunque el designado mostró su entera disposición para el servicio encomendado, éste no era fácil. Al mes y medio de estar ejerciéndolo ya era odiado y aborrecido por todos. Decía sentir una gran aflicción porque el salario no era tan sólo insuficiente para su sustento y vestuario, sino que no llegaba para mantener a

9 Ibidem. Cabildo de Nuestra Señora de Monterrey, 11 de noviembre de 1714. Adjunta testimonio de once testigos que declaraban el aumento de las hostilidades indígenas. Ibidem. Fray Juan de Losada al rey. México, 29 de julio de 1717. Ibidem. Manuel Ángel de Robles al virrey. Valle del Pilón (s/f). Se quejaba de que a los indios no los dejaron en las haciendas como gañanes. AGI, Guadalajara, 92. Oliván al rey. Guadalajara, 20 de marzo de 1714. Ibidem. Barbadillo al rey. México, 24 de abril de 1716. Zavala, Entradas, pp. 113-122. Se mencionan los capítulos de las ordenanzas que tratan de las funciones del protector con los indios. Montemayor, "La congrega", pp. 566-572. Hoyo, Historia, t. II, pp. 493-500. Patricia Osante: Orígenes del Nuevo Santander (1748-1772). México, Universidad Nacional Autónoma de México (UNAM), 1997, pp. 38-39. Cifra en más de mil los muertos por los indios. 
su extensa familia ni para obsequiar a los indios con tabaco, que era el imán que los atraía, lo que le obligaba a endeudarse. Y eso sin tener en cuenta otros gastos que se le ofrecían en el ejercicio de su cargo, como eran las provisiones y bestias necesarias para recorrer los caminos; papel común y sellado; manutención y sueldo a dos ayudantes y retribución al escribano que diese fe de sus diligencias. Además para Barbadillo resultaba incomprensible que, después de que el sueldo era escaso y no tenía suplementos, se le hubiese descontado la mitad por razón del pago del derecho de la media annata.

Evidenciaba la dificultad que estaba hallando en su ministerio por la falta de escribanos en ese territorio, tanto expertos como de confianza, pues entendía que eran "trovos coludidos a un mismo fin" y muy raro encontrar a alguien independiente por la coaligación de parentescos que existía. Explicaba que el escribano que había en Monterrey no sólo le tenía ojeriza por contar con familiares en ese lugar, sino que estaba físicamente imposibilitado para acompañarle. Así pues, pidió al virrey Valero que se pagara de la Real Hacienda a un escribano, dos escoltas y el tabaco para los indios.

El protector apoyó todo ello ante el máximo gobernante, sugiriendo que, en consideración al encarecimiento de la vida en ese lugar, el sueldo de los dos escoltas fuera de 150 pesos anuales a cada uno y a cuenta del Haber. Creía pertinente que a éstos no se les dedujera el derecho de la media annata, como se había practicado con Urrutia. Aprovechaba Barbadillo esta coyuntura para precisar que el empleo de protector tenía en esa tierra carácter militar, por eso se le daba el título de capitán y la ley exceptuaba de pagar tal arancel a los oficiales destinados a lugares en guerra viva.

Tampoco aprobaba este ministro que Urrutia tuviese que costear el papel que utilizaba en sus diligencias y planteó al virrey que pudiera hacerlas en cualquier pliego, aunque no fuese sellado, por la falta y sobreprecio en esa región. Con respecto al tabaco, juzgaba que era esencial por ser más valorado por los indios que los alimentos, aún en la mayor necesidad, y sin este producto no se conseguía nada provechoso de ellos. Reflexionaba que era el Erario quien debía de sufragarlo y con 100 pesos al año podrían comprarse 100 manojos para repartirlo y tenerlos, por el momento, satisfechos. En cuanto al escribano propuso que, como escaseaban y el único que había en Monterrey estaba enfermo, diera autorización a los escoltas para que actuasen como testigos de asistencia. 
Valero accedió a que el Fisco costeara los 300 pesos anuales de los dos escoltas, a los que facultó para testificar. A Urrutia le agradeció su esmero en el reciente cargo y determinó que se le entregaran únicamente 50 pesos para el tabaco destinado a los indios, alegando que "para contentarlos bastará, aunque no sea de la mejor calidad".

Más tarde, al habérsele concedido al protector la plaza de capitán del presidio de Río Grande, quedó vacante el puesto. Barbadillo, que ya en esa época era gobernador de Nuevo León (1719-1723), suspendió proveerlo hasta reconocer su urgencia y necesidad. No tardaría en comprobar lo esencial y preciso del mismo, tanto para la defensa de los indígenas como para acudir personalmente a los pueblos, en particular en la época de las siembras, a fin de incentivar a los indios al cultivo y rendimiento de las tierras. De no hacerse así, no se les podría proporcionar la ración de maíz que cada ocho días recibían y esto les forzaría a abandonar las poblaciones recién fundadas. ${ }^{10}$

\section{Nicolás de Villalobos}

En febrero de 1720, atendiendo a las reflexiones arriba descritas y a otras de igual peso y en un acto en el que, sin presencia de escribano por no haberlo ni real ni público en Monterrey, el gobernador Barbadillo, con la fórmula de "elijo, diputo y nombro", designó un nuevo protector general de indios de Nuevo León. Actuaron como testigos sus dos asistentes, Manuel de Velasco y Juan Muñoz de Herrera.

Al elegido, Nicolás de Villalobos, le fijó el mismo salario de 700 pesos al año que al ex protector Urrutia y pagados en la misma caja. A diferencia de su antecesor, no se le asignaron los 350 pesos para costear los dos escoltas y el tabaco, ya que según este gobernador, tal aumento podía excusarse al encontrarse él en ese territorio.

Barbadillo decía haberle escogido por ser "sujeto de todas prendas y en quien concurre lo necesario para lo mucho que tiene que trabajar un protector de indios". Aseveraba, que por sus "honrados procederes y obligaciones", habría de desempeñar ese ministerio de defender a los indígenas

10 AGI, Guadalajara, 166. Barbadillo al virrey y al monarca. México, 23 de marzo y 24 de abril de 1716. AGI, Guadalajara, 173. Urrutia a Valero. San Francisco de Mateguala, 19 de enero de 1717. Ibidem. Barbadillo a Valero y Decreto del virrey. México, 17 de febrero y $1 .^{\circ}$ de marzo de 1717. 
en todas sus causas civiles y criminales y con su asistencia personal a los pueblos durante el tiempo que juzgara preciso y conveniente, ciñéndose en todo a la Recopilación de las Leyes de Indias que trataban de esta materia, sobre lo cual le hacía "particularísimo encargo". Como disponían las ordenanzas de las nuevas fundaciones, en caso de notar omisión o poca aplicación en los gobernadores de ese Reino, presentaría queja ante el virrey. En su criterio, favorecía al designado el hecho de no ser vecino de Nuevo León ni sus contornos, sino que había llegado de España. ${ }^{11}$

En efecto, Nicolás de Villalobos, soltero, y cuyos rasgos físicos eran: de "buen cuerpo delgado, color blanco, ojos azules, cerrado de barba, cejas gruesas y pelo castaño claro", había nacido en Navalcarnero (Madrid) en 1687. Obtuvo licencia en abril de 1717 para pasar a Nueva España a la cobranza de unos bienes pertenecientes a una vecina de Sevilla. Después intervino como capitán de caballería en dos campañas que dicho gobernador emprendió contra los indios hostiles de Nuevo León. Satisfecho del gran celo que demostró y de su destreza y experiencia en la milicia, le otorgó el citado nombramiento con el requisito, como era reglamentario, de que fuese confirmado en México.

Barbadillo dispuso, por tanto, que Villalobos fuera ante el virrey Valero para la aprobación del título. Mientras, él mandaría que fuese admitido en el uso y ejercicio de este ministerio precediendo el juramento habitual. Consideraba que ese cargo era tan urgente e indispensable que había sido una gran suerte el conseguir que Villalobos lo desempeñara; por eso, pidió al virrey que le revalidara el título, reconociendo que en los cinco meses que estuvo vacante el puesto se habían dejado sentir las inconveniencias.

Cuando Villalobos se presentó ante Valero para que le confirmara el despacho, éste consultó primero con el fiscal de la Audiencia de México y se atuvo a su dictamen, de que el nombramiento le correspondía hacerlo a él por ser propio y privativo de su superior autoridad. En atención a lo cual, quedó anulado el primer título y se le expidió otro fechado el 9 de abril de 1720 con la orden de que hiciera el juramento del cargo y toma de posesión. Los términos en que estaba redactado el flamante documento eran

11 AGI, Guadalajara, 173. Nombramiento de protector. Monterrey, 21 de febrero de 1720 y Barbadillo al virrey. Nuevo Reino de León, 21 de febrero de 1720, en Testimonio de los Autos hechos sobre el empleo de capitán protector general de los indios del Nuevo Reino de León ("Testimonio empleo"), fs. 1-3v. 
prácticamente los mismos que el que se otorgó al primer protector José de Urrutia, al igual que el sueldo - 700 pesos- y los demás honores que gozó éste. ${ }^{12}$

\section{El repentino cese}

Habiendo mostrado Villalobos el nuevo título a Barbadillo para los debidos ceremoniales, no consintió en hacerlo y retuvo el despacho. Ante esta extraña y firme actitud, acudiría al virrey para lograr que aquel aclarase los motivos. Estaba convencido de que esto se debía a que el gobernador recelaba que fue idea suya la revocación que de su nombramiento hizo Valero y a que en las ordenanzas para los recién fundados pueblos de indios se le inhibía de su jurisdicción. Intentó que el máximo gobernante le diese otro y le permitiera hacer la jura ante cualquier ministro de la Audiencia de México para evitar que le ocurriera lo mismo si iba a Nuevo León, así como que se le proporcionaran dos escoltas, al igual que se hizo con su antecesor. No consiguió ninguna de las peticiones. ${ }^{13}$

Sin atender al dictamen del fiscal de la Audiencia, que se inclinaba por acceder a las demandas de Villalobos, el virrey Valero, en octubre y por segunda vez en diciembre de 1720 , pediría explicaciones a Barbadillo por la gran extrañeza que le había causado su proceder. En su tardía respuesta, a finales de enero de 1721, reconocía el gobernador haberse equivocado en la elección. Aseguraba que ya antes de solicitar la confirmación del título, dio "notorias muestras de lo poco que promete su talento" y de la ninguna unión con los misioneros, algo tan esencial en el ejercicio de su labor. Había intentado corregir sus desordenadas ideas reteniendo el despacho para ver si, con "blandura y arte", podía moderar su temperamento, pero comprobó que era perjudicial y revoltoso y su genio y operaciones inapropiados para el uso y manejo de ese oficio. Sugería que podría ejercerlo él personalmente mientras fuese gobernador, pese al mucho trabajo. Los 700

12 AGI, Contratación, 5469, N. 1, R. 42. Expediente de información y licencia de pasajeros a Nicolás Mellizo Villalobos. Cádiz, 13 y 15 de julio de 1717; y Memorial de Villalobos (s/f). Él mismo expresa en unos documentos que era de Navalcarnero y en otros de la Villa de Madrid. AGI, Guadalajara, 173. Barbadillo al virrey. Monterrey, 21 de febrero de 1726; Respuesta del fiscal. México, 18 de agosto de 1721; Valero a Barbadillo. México, 28 de septiembre y 18 de octubre de 1720 y Nombramiento de Villalobos. México, 9 de abril de 1720 en "Testimonio empleo", fs. 1-9 y 27-30.

13 AGI, Guadalajara, 173. Villalobos al virrey (s/f) en "Testimonio empleo", fs. 3-5. Ibidem. Villalobos al virrey. Jalapa, 7 de febrero de 1721 , fs. $6 \mathrm{v}-7 \mathrm{v}$. 
pesos de salario se emplearían en la compra de armas para que en tiempos de guerra con los indios ningún vecino se excusara de salir por falta de ellas, como sucedía. Las armas se guardarían en una sala de su vivienda habilitada para ello.

Una carta similar recibió Valero meses antes firmada por el comisario de las misiones de Nuevo León, fray Juan de Losada - amigo y colaborador de Barbadillo en su etapa de visitador - y varios misioneros de cuatro pueblos recién fundados. En ella, aparte de referir que Villalobos era "notoriamente revoltoso, sin inteligencia ni espera de hombre para lance alguno" y que había cometido grandes desatinos "sin caberle ya el empleo de protector que todavía no tenía", insinuaba que el gobernador no se fuera, ya que si faltara podría alterarse la provincia por los disturbios que sembraba y causaba ese sujeto.

Atendiendo a estas reflexiones y al dictamen del auditor de guerra, Juan de Oliván, que aconsejaba recoger el despacho, el virrey determinó que no hubiera capitán protector general de indios en esa región, "por los justísimos motivos que tengo", desestimando los memoriales del interesado, donde insistía en la restitución de su plaza. Lo mismo declararía más tarde el Consejo de Indias, ordenando que se suspendiese a Villalobos. ${ }^{14}$

¿Quién era realmente este individuo? ¿Cuáles sus méritos para que Barbadillo lo hubiese llevado consigo a Nuevo León, lo tuviera en su casa, lo agasajara y hubiere confiado en él con tanta convicción para darle un puesto de responsabilidad, aunque luego se retractara? El nombre completo respondía al de Nicolás Mellizo de Villalobos y era hijo legítimo de Matías Mellizo de Villalobos y Ana Fernández Frejomil. Su padre, sus tíos (Hipólito de Villalobos, Felipe Valero, Antonio Frejomil) y otros parientes ocuparon cargos de autoridad y graduación en la milicia y en los reales Consejos.

Sus comienzos, en abril de 1703, cuando tenía 16 años de edad, fueron como cadete aventurero en el regimiento de dragones llamado "de la Muerte" en Badajoz y estuvo allí hasta 1708, costeando sus armas y caballos. Durante esa etapa participó en la toma de Orihuela y Elche y en otras funciones en el Reino de Valencia. Habiéndose embarcado en Málaga con

14 AGI, Guadalajara, 173. Barbadillo a Valero. Monterrey, 28 de enero de 1721; Dictamen del Auditor de Guerra. México, 4 de septiembre de 1721 y Decreto del virrey. México, 23 de julio de 1721 en "Testimonio empleo", fs. 11-17v. Ibidem. Los frailes Juan de Losada, Sebastián de Torres y otros al virrey. Nuevo León, 24 de abril de 1721. AGI, México, 381. Consejo de Indias al rey. Madrid, 14 de octubre de 1726. 
destino a Cartagena (Murcia) a fin de incorporarse a las tropas del mando del conde de Mahoni que iba a Sicilia, fue hecho prisionero y llevado junto con otros a la plaza de Alicante, ocupada entonces por los ingleses.

Una vez canjeado, obtuvo permiso del conde de Charny, inspector general de infantería, para reincorporarse a su unidad. Participó en todas las operaciones contra los adversarios en la frontera portuguesa, en cuyos encuentros recibió cuatro graves heridas. Por fallecimiento del coronel de su regimiento, Antonio de Leiva, y con la misma calidad de cadete aventurero, se agregó a la compañía coronela del regimiento de caballería Viejo de Extremadura donde estuvo durante más de cuatro años, pagando también a su costa sus caballos y armas. Intervino en la batalla de La Gudiña y sitio de Campo Real, donde quedó gravemente herido. En todas estas actuaciones sus superiores destacaron "su ardiente celo en el real servicio", "su gran honra" y su valor.

Al no haber en su unidad vacante acorde a sus méritos, el coronel del mismo, el marqués de Lorenzana, le dio licencia el 19 de julio de 1712 para que pasara a servir un cargo en la Proveeduría general del Ejército y plazas de Andalucía. Se le concedió el de factor proveedor general y en él estuvo durante 1714-1715. Aquí sus jefes ensalzaron igualmente su "incansable aplicación" y estimaron que era digno de cualquier merced y empleo con que el monarca quisiera distinguirle. ${ }^{15}$ Después, como ya hemos explicado, pasó a Indias y estuvo a las órdenes de Barbadillo hasta que se produjo la súbita destitución a raíz de la cual emprendió una particular cruzada, que duró varios años, para recobrar su honor y su puesto. Esa etapa coincidió, fundamentalmente, con los gobiernos de los virreyes de Nueva España marqueses de Valero y de Casafuerte y con el ya citado gobernador de Nuevo León y su sucesor, Juan José de Arriaga Brambila.

\section{El incansable peregrinar}

Villalobos tuvo que refugiarse en el convento jesuita de San Francisco Javier de Monterrey por el atropellamiento que decía recibir de Barbadillo al haber dejado de asistirle, tras su negativa a facilitar el pase al título.

15 AGI, Indiferente General, 144, N. 68 y 145, N. 21. Relación de los méritos y servicios del capitán de caballos Nicolás de Villalobos. Madrid, 16 de septiembre de 1729 y 3 de octubre de 1731. Ibidem. Memorial de Nicolás de Villalobos al rey. (s/f). AGI, Contratación, 5482A. Memorial de Villalobos al rey. Madrid, 15 de febrero de 1735. 
Según parece, por orden suya y con el propósito de lograr su arresto y con ello su deshonra, los padres Pedro Aparicio y Luis Camacho le instaron a que lo abandonase para no indisponerse con el gobernador, por lo cual se vio obligado a pedir ayuda al cura vicario a fin de que lo acogiera en su iglesia.

Llegaría a declarar que era público que el responsable de lo que ocurría era fray Sebastián de Torres, ministro doctrinero del pueblo de Guadalupe, quien presionaba para que el cargo se lo dieran al alcalde ordinario de Monterrey Joaquín de Escamilla.

En agosto de 1720 había llegado a consultar con el padre rector del citado convento, Ignacio Báez Treviño, para que le aconsejara si debía de defender su reputación o abandonar esta idea. Del mismo modo, deseaba que atestiguase si sabía o había escuchado quejas contra su persona. La respuesta fue la siguiente:

Es por muy natural atender cada uno a su crédito y defenderlo mucho, y más, en las personas de las cualidades y prendas de vuestra merced, muy apreciadas en este lugar por su cristiano, noble y muy honrado proceder, con que no sólo no ha ofendido a otros, sino porque de muchos que están obligados de sus atenciones y así juzgo que vuestra merced puede y debe parecer ante juez competente procurando el buen lustre de su crédito. Así lo siento.

También el franciscano fray José Alonso declaraba haber oído comentar y comprobado personalmente sus cualidades y buenas maneras con todos. Confirmaba ser ciertos los ultrajes de Barbadillo, habiéndole llegado a quitar incluso la silla de montar para que no fuera a México a dar cuenta al virrey. Había tomado gran inquina a los que le ayudaron, por lo que juzgaba que ninguna persona habría de apoyarlo por no enemistarse con el mandatario. El fraile le daría su silla de montar y víveres para el camino.

A favor de Villalobos se inclinaron, de igual forma, Lucas de las Casas, cura beneficiado de Saltillo, y el colegial del Seminario de Monterrey José González Hidalgo. El primero aseveraba que muchos se habían condolido de que no hubiere surtido efecto el nombramiento del virrey. Atribuían la interrupción al pase del título y su ejercicio no a su falta de aptitudes, sino a que se le excluía de la competencia del gobernador. ${ }^{16}$

16 AGI, Guadalajara, 173. Certificación de fray José Alonso. Monterrey, 18 de agosto de 1720 en Testimonios de certificaciones ("Certificaciones"), fs. 3-3v. Ibidem. Villalobos a Báez Treviño. Convento de San Francisco de Monterrey, 17 de agosto de 1720 y Respuesta del rector. Monterrey, 17 de agosto de 1720, fs.1-2. Ibidem. Villalobos al padre Alonso. Monterrey, sin fecha, fs. 2-2v. Ibidem. Certificaciones de Lucas de las Casas y de Bartolomé González Hidalgo. México, 3 de octubre de 1722, fs. 3-6. 
Tampoco tuvo fortuna en México, donde permaneció varios meses. Allí fueron también un grupo de indios del pueblo de la Concepción pretendiendo, entre otras cosas, que el virrey de turno, Casafuerte, les restituyera al protector. Otros pedirían que se les diera licencia y facilitaran caudales para conducir familias tlaxcaltecas, herramientas y demás útiles a San Cristóbal de los Gualahuises para reparar la despoblación y los daños acontecidos por su falta. El virrey les recomendó que regresaran a sus pueblos por no haber fondos en las Cajas de México, prometiéndoles que se tendría presente este asunto para dar pronta providencia. Ya por entonces había otro gobernador. A Barbadillo se le requirió para reincorporarse a su plaza en la Audiencia de México. Le sucedió Juan José de Arriaga, quien tomó posesión del cargo el 5 de mayo de $1723 .{ }^{17}$

El nuevo gobernante se encontró con que los indios gentiles y apostatas de esa región tenían amedrentados a sus moradores con sus asaltos, muertes, robos, secuestros y otras tropelías. Estos rigores, que eran cotidianos, los habían ejecutado, según le informaron a su llegada un grupo de vecinos que acudieron a pedirle justicia, en los años que estuvo Barbadillo en ese gobierno. Por no haber dado su consentimiento para que se les castigara, se habían insolentado de tal modo que llegaron al extremo de colocar en el camino de Boca de Leones banderas teñidas de sangre en señal de guerra, en la cual se mantuvieron. Durante ese tiempo, constaba por certificación de los alcaldes mayores de ese distrito que mataron a 732 personas, sin respetar a mujeres ni a niños, robaron más de 43.000 cabezas de ganado y se despoblaron trece haciendas y ranchos.

Arriaga había informado al virrey en agosto y en septiembre de 1723 acerca de sus providencias para contener la osadía de los indígenas. Le explicaba haber encomendado al sargento mayor Fernando Sánchez de Zamora su seguimiento y castigo con 40 hombres, quienes mataron a nueve indios y apresaron a siete muchachos que repartieron entre los soldados. En campaña tuvo dos escuadras con 60 y 70 hombres, respectivamente. La primera había matado a 37 enemigos y capturado a 26 , que fueron igualmente repartidos. El virrey le felicitaría por ello, pero quiso que se le informara de con qué fin se aplicaban los prisioneros a los soldados.

17 AGI, Guadalajara, 173. Certificación de Simón Nieto de Alvarado. México, 18 de febrero de 1726. Ibidem. Decreto de Casafuerte. México, 26 de febrero de 1726. Zavala, Entradas, pp. 125-128. Faltaban ministros por haber sido cesados algunos de ellos por Francisco de Garzarón. Información al respecto en María Luz Alonso: "La visita de Garzarón a la Audiencia de México: Notas para su estudio", en Estudios jurídicos en homenaje al maestro Guillermo Floris Margadant. México, UNAM, 1988, pp. 11-27. 
Con más detalle aclararía Arriaga que viendo que al mes de estar en el gobierno fueron muchas las muertes y robos que seguían efectuando los indígenas, incluidos los de los pueblos fundados, quienes divididos en diecisiete escuadras con un copioso número de ellos en cada una atacaban por diversas partes de ese territorio, les hizo guerra justa y defensiva. De su bolsillo, por no haber fondos para gastos de guerra, decía haber costeado siete escuadras, tres de a cien hombres y cuatro de a cincuenta, caballos, armas, víveres y pólvora. El fruto después de siete meses de campaña fue el sosegarse esa provincia; se volvieron a poblar las haciendas y ranchos; los vecinos pudieron criar sus ganados y abastecer de carne a la ciudad de México; cultivar sus tierras y beneficiar las minas de Boca de Leones, las de Salinas y las de las jurisdicciones colindantes. Muchos indígenas pidieron la paz y respecto a los capturados expresaba que fueron llevados a casas de buenas familias para que los educasen cristianamente, pues si retornaban a sus pueblos se fugaban y volvían a su "barbaridad, fiereza, indevoción y apostasía". ${ }^{18}$

De manera muy distinta calificaron Villalobos, el regidor Luís García de Pruneda y otros la actuación de Arriaga al considerar que no era guerra justa ni defensiva la que había ejecutado sino ofensiva. El primero dio cuenta al Consejo de los atroces homicidios y las ventas que se habían practicado pidiendo que para su remedio se le restituyese a su puesto. Sostenía que en esa causa estaban involucrados ministros de la Audiencia de México como el marqués de Villahermosa de Alfaro, por no haber querido escuchar, en su condición de juez general del Juzgado de Indios, a los que de Nuevo León habían ido a pedir justicia; también José Gutiérrez de la Peña, "declarado enemigo de los indios y defensor juez protector de los agresores" y Pedro Malo de Villavicencio, muy estrecho amigo del capitán Francisco de Arriaga y del gobernador, su padre, "agresor de estos estragos" con la protección del virrey.

García de Pruneda manifestaba que era tanta la pasión del virrey Casafuerte a favor de Arriaga que mandó prender y castigar a los indígenas que fueron a quejarse de las violentas e injustas muertes y desolación cau-

18 AGI, Escribanía, 204A. Certificación de Miguel Leal de León. Villa de Cadereyta, 21 de mayo de 1725 en legajo 46 de pleitos de México núm. 2, pieza 4, fs. 38-38v. Ibidem. Memorial de Francisco Antonio de Rosales, en nombre de Arriaga, al virrey. AGI, México, 566. Declaración de Marcos de Ochoa. Monterrey, 6 de mayo de 1724. AGI, Guadalajara, 173. Casafuerte a Arriaga. México, 8 de octubre de 1723. Ibidem. Certificación de Juan Álvarez de la Plata. México, 26 de junio de 1725 . 
sadas por aquel y sus soldados, la mayoría de los cuales murieron en las cárceles de México sin confesión. ${ }^{19}$

El cura y vicario de la ciudad de Monterrey, Juan de Arellano, declaraba que a los indios que apresaban en las campañas los repartían de la siguiente forma: se separaba el quinto para gastos de guerra; el capitán de la expedición apartaba los que les parecían para él y el gobernador y el resto se distribuía entre los soldados.

Casafuerte, aunque en un principio felicitó a Arriaga por su gestión, no tardó en advertirle que si la guerra había sido ofensiva era algo reprobable, como también lo era el que los oficiales y soldados indisciplinados se creyeran que podían salir a lo que llamaban campañas, pero que realmente eran "caza de gentiles y batidas de indios", de la misma forma que si se tratara de fieras. Le ordenó que se ajustara a las Leyes.

El Consejo pediría informes en 1724 y 1726 al virrey enviándole copias de los memoriales remitidos por Villalobos. Casafuerte no contestó por entonces y desde el Consejo se le volvería a insistir en mayo de 1728. Al fin manifestaría que los alegatos de Villalobos y su pretensión a la protectoría eran totalmente desestimables y no tenían conexión alguna con las matanzas de indios que se habían producido en Nuevo León. ${ }^{20}$

\section{Entramado de intereses}

Los numerosos memoriales que Villalobos dirigió a la máxima autoridad virreinal y al gobierno de Madrid desde que se le cesó; el destierro; su petición de ayuda a los ministros Andrés de Pez y José de Grimaldo; sus viajes; el gasto que le ocasionó esta empresa y otras penalidades sufridas, reflejan el gran esfuerzo de este hombre por recobrar por todas las vías posibles un empleo que se le había arrebatado de improviso, aunque el pre-

19 AGI, Guadalajara, 173. Villalobos al rey. México, 4 de octubre de 1726 y 28 de mayo de 1728. AGI, Escribanía, 204A. García de Pruneda al virrey. México, 4 de mayo de 1728, en Compulsa de testimonios originales. Pieza 3. Año 1728, fs. 1-1v. AGI, Guadalajara, 118. Certificación de Manuel Reyes Vivanco. Monterrey, 28 de abril de 1724. Este comisario de la Santa Hermandad afirma con testimonios que fue el gobernador Arriaga quien había dado las órdenes para las nuevas muertes y daños que habían sucedido en los pueblos de indios, rancherías de paz, montes y despoblados. Ibidem. García de Pruneda al rey (s/f).

20 AGI, Guadalajara, 173. Juan de Arellano al virrey. Monterrey, 9 de junio de 1724. Ibidem. Decreto de Casafuerte. México, 22 de abril de 1724. La orden iba dirigida de igual forma a otros gobernadores de fronteras. Ibidem. Real cédula al virrey de Nueva España. Madrid, 2 de octubre de 1728. AGI, México, 567. Extracto para despachar en el Consejo. Madrid, 27 de junio de 1731. 
texto, verdadero o no, fuera su defensa de los indios. Sin embargo, este caso revelaría también la existencia de una trama de intereses en la que las parcialidades y la corrupción estuvieron presentes y que en la medida de lo posible trataremos de desenredar.

Cierto es que en los comienzos de esta historia, Barbadillo, al igual que lo hicieron primero los religiosos, censuró la cavilosidad de Villalobos, su escasa inteligencia, su engreimiento con el cargo e ineptitud para el mismo, cuando poco antes había dicho todo lo contrario. No obstante, ni el uno ni los otros detallaron hechos concretos de su díscola y altiva conducta, ni hubo declaración de testigos, ni demandas judiciales por parte de algún posible afectado que justificaran el cese. El propio Villalobos estaba en la incertidumbre de si había servido dicho empleo o no e intentó que se lo aclararan. Si se estimara que lo había ejercido quería saber cual fue el motivo de la suspensión y, en caso contrario, no existía causa para tal cese. Aseguraba estar dispuesto a "dar plenísima satisfacción a la más mínima queja que se hubiere dado contra mí y cuando no la diere que se me castigue conforme al delito".

Denunciaba Villalobos que como él no se amoldaba a lo que el gobernador definía como "esencia del empleo", que era el consentimiento de lo que se estaba haciendo con los indios y, "además, no era lisonjero", lo tachaban de "inquieto, revoltoso e inhábil". En su opinión, la carta de los jesuitas en su contra era falsa y se debía al poder de Barbadillo como gobernador y aún más siendo ministro togado. Afirmaba que a los de la Compañía, al ser dueños de haciendas en ese territorio e interesados en el servicio personal de los indios, no les traía cuenta que hubiera protector, porque él no permitía iniquidades, defendía la justicia y los amparaba, sin consentir que se quedaran "con el sudor y trabajo de estos pobres". Pensaba que a los indígenas debían de repartírseles tierras y agua para que cultivaran por sí mismos sin que los misioneros intervinieran en la siembra y recolección, ya que aquellos no necesitaban "comer por mano ajena".Y respecto a su relación con los frailes precisaba que sería buena si ellos y todos los enemigos de los indios fueran al fin que él iba. Tenía la certeza de que aunque sus rivales "asestan el tiro y disparan contra mí, no es el blanco donde tiran a mi persona, sino al empleo". ${ }^{21}$

21 AGI, Guadalajara, 173. Villalobos a Andrés de Pez y al marqués de Grimaldo. México, 30 de septiembre de 1722 y 15 de mayo de 1725. Ibidem. Villalobos al rey. México, 30 de septiembre de 1722; 16 de julio y 4 de octubre de 1726; 6 de mayo de 1727 y 9 de octubre de 1728 . 
Estas y otras acusaciones sobre la resistencia de las autoridades y vecinos de Nuevo León al establecimiento y permanencia de los pueblos de indios, no eran más que una situación semejante a la que había encontrado Barbadillo años atrás en la comisión de la visita y revelado con anterioridad el duque de Linares. El virrey había hecho una llamada de atención acerca de que en ese Reino había "descamisados" propietarios de tierras de 50 y 100 leguas de contorno por merced de los gobernadores. En cambio, no existía ni un palmo de terreno para crear tales pueblos sin que surgieran multitud de inconvenientes. Lo atribuía tanto a que los dueños no querían desprenderse de las tierras como a que perdían las ventajas adquiridas teniéndolos en las congregas.

En esta red de intereses podemos suponer que a Barbadillo no le agradó que el nombramiento a Villalobos no le fuera confirmado por el virrey. También es perceptible que su papel como gobernador era substancialmente distinto del que tuvo antes como visitador. En el periodo de su comisión llegó a manifestar, en lo relativo a los gobernadores de esa zona, que no administraban justicia y sólo atendían a sus conveniencias y al desempeño de las deudas que llevaban contraídas. Y es que, al ser tan públicas y comunes las voces de las crueldades que se habían cometido con los indígenas, hizo que el escribano le proporcionara una certificación de las causas que se hubiesen fulminado contra españoles de diez años a esa parte por esta razón y quedó sorprendido de que no constara ninguna. Según le habían asegurado algunos curas, el matar indios en esa tierra no se consideraba "materia en que recayese la absolución". ${ }^{22}$

Villalobos era del mismo sentir en relación a los gobernadores durante el tiempo en que Barbadillo ejercía como tal en ese Reino. Argumentaba que el único fin de estos mandatarios no era otro que "el de su interés, coger el sueldo y aniquilar a los indios y esclavizarlos". Aunque Villalobos no entraba en enjuiciar si esta persona pretendía la esclavitud o libertad de aquellos, lo que sí creía era que por su causa se había experimentado la opresión y ruina en los pueblos. Otros, por el contrario, alabarían su gestión.

Si bien Barbadillo en ambos ministerios, visitador y gobernador, defendía la importancia del empleo de protector en esa tierra, de igual manera queda demostrado que como gobernador intentó ejercerlo él perso-

22 AGI, Guadalajara, 166. Linares al rey. México, 20 de septiembre de 1715. Ibidem, Barbadillo al rey. México, 24 de abril de 1716. Zavala, Entradas, pp. 113-114. 
nalmente con la apariencia de ser de balde y emplear los 700 pesos del sueldo en la adquisición de armas. Esta actitud choca con su postura anterior y con lo contenido en uno de los capítulos de las ordenanzas que para los pueblos de indios había formado él mismo y en el que se recogía que el protector debía de quedar inhibido de la jurisdicción del gobernador.

Villalobos le reprochaba que su disposición para desempeñar el puesto gratuitamente eran "ardides de la codicia para lograr más su interés y no tener encima quien le reprima y abstenga sujetando sus iniquidades". Por eso defendía el cesado protector, en su propio beneficio, que el empleo fuera independiente del gobernador. En su criterio, el proyecto de Barbadillo de comprar armas y tenerlas dispuestas para cuando hiciesen falta era una idea poco práctica, ya que habría que pagar a personas que se encargaran de su continuo cuidado por ignorarse la hora de su uso, que nunca llegaría, pues los asaltos de los indios eran repentinos y simultáneos en distintos parajes. ${ }^{23}$

Del mismo modo es significativo que, pese a que Barbadillo había manifestado que el cargo de protector no convenía que lo ejerciera un vecino de Nuevo León, pretendiera esa plaza después de la inhabilitación de Villalobos su asistente y testigo del nombramiento de éste, Juan Muñoz de Herrera. El asistente era yerno del teniente de gobernador de ese Reino, Luís García de Pruneda, amigo de Barbadillo y persona de mucho arraigo e influencia en esa región, debido a la saga de gobernadores que hubo en su familia (su tío Domingo de Pruneda, su hermano Cipriano García de Pruneda y su suegro Alonso de León que, además, era descendiente de conquistadores). También Luís García de Pruneda había ejercido ese puesto en 1708 y brevemente en interinidad en 1723 a la marcha de Barbadillo, a más de desempeñar varias comisiones.

Esta persona era a la vez y desde hacía unos diez años, aunque no había pedido la confirmación, regidor decano y alcalde provincial de Monterrey y su hijo Juan García de Pruneda regidor y alguacil mayor del mismo Ayuntamiento. Al ser éste menor de edad servía su cargo un teniente, pero quien en realidad ejercía estos dos oficios era el padre y como el otro regidor y alférez real, Antonio López de Villegas, no acudía por estar enfermo o si iba "por no ahorcarse convenía en el dictamen de D. Luís", no había quien pudiera oponerse a la voluntad de Pruneda padre, el cual goza-

23 AGI, Guadalajara, 173. Villalobos al rey. México, 30 de septiembre de 1722 y 6 de mayo de 1727. 
ba del poder total de "abrir y cerrar la puerta en dicho cabildo". Con ese conjunto de cargos consolidaba, pues, García de Pruneda el más absoluto despotismo que había padecido esa región en la cual poseía tiendas y un gran número de propiedades. ${ }^{24}$

Ignacio Báez Treviño, el religioso que anteriormente había alabado las virtudes y buen proceder de Villalobos, junto con el maestro de estudiantes del Colegio de San Javier de Monterrey, Bernaldino de Baraldúa, sería el que estando aquel en plena campaña para intentar recobrar el empleo y en respuesta a una consulta del virrey Casafuerte en 1723 acerca de si había necesidad de protector de indios en esa región, manifestó que no eran precisos ya que los gobernadores los habían atendido siempre "con gran amor y caridad" y sin costo alguno para la Real Hacienda.

En su opinión, los protectores eran "hombres pobres fallidos" propensos a no omitir ningún fraude y a esclavizar a los naturales haciendo que en cada pueblo les sembraran una fanega de maíz y si no recibían alguna dádiva de los vecinos que les pedían indios para su servicio, los dejaban sin ellos. Aseguraban que para tenerlos contentos les consentían toda clase de vicios y delitos. Recordaremos que este jesuita era hijo de Francisco Báez Treviño, gobernador por dos veces de Nuevo León, la segunda en la época en que Barbadillo había sido visitador, y ya conocemos la opinión que éste tenía de él y de otros gobernadores de esa región. Hay que tener presente que en esa tierra sólo habían existido dos protectores -Urrutia y Villalobos - y al primero ya hemos visto cómo el virrey Valero le felicitó por su buen hacer en este destino, por lo que parece que sus críticas iban dirigidas, principalmente, a Villalobos.

En cambio, Báez Treviño y Baraldúa no escatimaban elogios en pro del gobernador de ese momento, Juan José de Arriaga, quien pasaba por un complicado trance a consecuencia de su controvertida actuación con los indios y en especial por su sonado enfrentamiento con el regidor Luis García de Pruneda, al que insultó y agredió.

Este segundo hecho, al que se encadenarían otros de distinta índole, exagerado por García de Pruneda con testimonios de sus parciales y de tes-

24 AGI, México 566. Certificación del capitán Francisco Javier de Escamilla. Nuestra Señora de Monterrey, 20 de agosto de 1723. Era alcalde ordinario y el escrito no iba refrendado de escribano por que no lo había. AGI, Escribanía, 204A. Petición de Francisco Antonio de Rosales, en nombre de Arriaga, al virrey (s/f). AGI, Guadalajara, 173. Petición de Juan Francisco de Córdoba, en nombre de Juan Muñoz de Herrera, al virrey (s/f) y Petición de Antonio José Vidaurre, en nombre de Villalobos, al virrey (s/f), en "Testimonio empleo", fs. 17v.-18 y 18v.-26v. 
tigos al parecer comprados, le supuso en principio a Arriaga el destierro 30 leguas en torno de Monterrey mientras un comisionado por el virrey, Antonio Bustamante, hacía las correspondientes averiguaciones, por lo que dejó como sustituto en el gobierno a Pedro de Sarabia Cortés. A Sarabia también se le atribuyeron desmanes contra los indios, estimándose que tanto él como los demás gobernadores de Nuevo León lo que buscaban era exterminarlos y destruir los pueblos para apoderarse de las tierras. ${ }^{25}$

En cuanto a las intenciones de Villalobos, es obvio que en sus escritos había cierta dramatización acerca de la ruina de ese Reino y del proceder de los gobernadores, hacendados, pastores, curas y demás con los indígenas. En su dilatado camino reivindicativo supo aprovechar unos lamentables y concretos sucesos que se produjeron en ese tiempo para atribuirlos a la falta de protector y alcanzar su objetivo de recuperar la plaza. Claro que, en esta red de conveniencias, García de Pruneda utilizó también las denuncias de Villalobos sobre las iniquidades cometidas por Arriaga y sus capitanes con los indios en beneficio propio y tapadera de algunos de sus ya habituales desmanes, ya que, como hemos referido, mantenía una palpable rivalidad con dicho gobernador.

Arriaga, por su parte, no consideraba a Villalobos apto para ese destino por caviloso y coincidía con la voluntad de Casafuerte de suprimir el empleo por inútil y costoso, alegando que los gobernadores siempre atendían al buen tratamiento de los indios. Este gobernante, al que algunos de sus defensores reconocían como "el nuevo conquistador y pacificador de Nuevo León", se arrogaba haber asistido en persona con diversos capitanes a más de 40 campañas contra los indios infieles y apóstatas, de las cuales 18 fueron victorias y todo a expensas de su caudal. ${ }^{26}$

De la misma manera, Luis García de Pruneda se vanagloriaba de haber ayudado a Barbadillo como nadie en la fundación de los cinco pueblos de indios; de ser el único que había hecho prevalecer la justicia y la

25 AGI, Guadalajara, 173. Certificación de Marcelino de Baraldúa y de Simón Nieto. Misión de Guayamota, 16 de septiembre de 1726 y México, 3 de agosto de 1727. AGI, México, 566. Petición de Juan de Meñaca, en nombre de Arriaga, al rey (s/f). AGI, Guadalajara, 118. Certificación de Juan Álvarez de la Plata. México, 26 de junio de 1725. Más información del grave conflicto Arriaga-Pruneda en nuestro artículo "Pulso entre poderes en Nuevo León: el gobernador Arriaga y el regidor García de Pruneda, 1723-1731" en preparación.

26 AGI, Guadalajara, 173. Arriaga al rey. México, 5 de octubre de 1726. AGI, México, 566. Certificación de José Antonio Fernández Vallejo. Santiago de las Sabinas, 14 de noviembre de 1724. Estas y otras certificaciones similares contenidas en el mismo legajo alaban la actuación de Arriaga como gobernador y algunos declaran que era merecedor de continuar en el cargo de forma vitalicia. 
razón "en defensa del pobre desvalido, por lo cual los gobernadores y sus parciales le tenían ojeriza". Por contra, otros denunciaban sus atropellos llamándolo "tirano de honras y haciendas" y señalaban que las campañas las había hecho con dinero ajeno, a tenor de lo sucedido con una que efectuó el capitán Salvador de la Garza pagada de su bolsillo y aquel quiso que le diera una certificación donde constara que había sido sufragada por él, a lo cual se negó el capitán. ${ }^{27}$

Villalobos, a su vez y pese a su fulminante destitución, se preciaba de haber cumplido exactamente como protector con lo que se le había ordenado. En su hoja de servicios figura que practicó todas las diligencias encaminadas al amparo y defensa de los indios de Nuevo León, habiendo conquistado y reducido a más de cuatro mil, a los que puso en ocho pueblos que estableció junto con familias de tlaxcaltecas que trajo de la misma ciudad de Tlaxcala y de otros lugares sin costo alguno de la Real Hacienda. Decía haber gastado todo su caudal por el excesivo trabajo que conllevaba este empleo, ya que se recorría las 200 leguas de extensión que tenía aproximadamente ese Reino visitando los pueblos de indios, gestionando su aumento y agasajándolos con regalos para conseguir su reducción al gremio de la Iglesia y obediencia al monarca. ${ }^{28}$

La total veracidad de los abultados méritos de unos y otros logrados en Nuevo León, así como de todo lo sucedido en este caso que estudiamos, sin someterlos a tela de juicio, quedan al menos en entredicho si atendemos a la diversidad de rumores que se hacían circular según conviniera a unos u otros, a las redes familiares y clientelares, a lo que afirmó el protector Urrutia acerca de la falta de independencia de los escribanos de esa provincia, ya expuesto, o a lo que declaraban Arriaga y otros en relación con García de Pruneda. Al parecer, Francisco de Mier Noriega -que había adquirido la plaza de escribano público de Monterrey con dinero de Pruneda con la condición de que habían de ir a medias en los derechos y aún de pagarle un 7\%- le dio varios testimonios falsos y entre ellos algunos sobre méritos y servicios que aquel no había efectuado. ${ }^{29}$

27 AGI, Indiferente General, 148, N. 23. Relación de méritos de Luis García de Pruneda. Madrid, 15 de marzo de 1738. AGI, Escribanía, 204A. Memorial de Francisco Antonio de Rosales, en nombre de Arriaga, al virrey (s/f).

28 AGI, Indiferente General, 144, N. 68. Relación de meritos y servicios del capitán Nicolás de Villalobos. Madrid, 16 de septiembre de 1734. Ibidem. Memorial de Villalobos. (s/f). Otra relación de servicios en AGI, Guadalajara, 118. Madrid, 26 de octubre de 1734.

29 AGI, México 566. Certificación del capitán Francisco Javier de Escamilla. Nuestra Señora de Monterrey, 20 de agosto de 1723. 
La gran baza que supo utilizar Villalobos en su provecho, como se ha apuntado, fueron las injustas muertes de indios en las campañas de Arriaga y de algunos de sus capitanes. Quizás por eso Casafuerte, que ya manifestó que no tenían relación alguna con la falta de protector y que ese asunto ya había sido juzgado debidamente, dijera de él que lo que había representado, tanto en México como luego en Madrid, no había sido más que "una genial sedición, pues aunque en el caso de que sin causa justa se le hubiera suspendido el nombramiento, no habiendo tenido la posesión del cargo no se le hacía agravio ni injusticia en la retención”. Estaba persuadido de que sus recursos habían sido subrepticios, "mal fundados sus derechos y maliciosos los fines de conseguir de V.M. lo que aquí se le denegó".

Sugería el virrey que si el monarca deseaba concederle algún empleo a este sujeto, fuese en una ocupación que no se mezclara con indios. Insistía en que no se le diera el de protector, porque estos cargos eran "inútiles y aún nocivos a las provincias" y a aquellos les suponía dilación en sus causas, sirviendo sólo de gravamen al Erario. De hecho, lo que practicó esta autoridad fue observar lo ya resuelto antes de su llegada al Virreinato, es decir, que no era necesario el empleo de protector de indios y que Villalobos carecía de capacidad para desempeñarlo. Y en consecuencia, afirmaba haberlos quitado de todos los lugares en que los había. Suprimiría, además, la plaza de fiscal protector de indios del distrito y jurisdicción de la Audiencia de México ocupada por Felipe Tineo. ${ }^{30}$

Por otro lado, esta claro que la conducta de Villalobos incomodaba a muchos, incluso del entorno del virrey, con intereses en Nuevo León. Conforme a una certificación del escribano que lo acompañó en México, un oficial del superior gobierno del cargo de José Morán llamado José Zorrilla, le dijo en tono alterado y amenazante:

No basta de la manera que trae a tanto hombre honrado con lo que ha escrito a España por cuatro indios perros chichimecos que debieran ahorcarlos a todos que no quedara ninguno y entonces estuviera el reino mejor, que no tiene la culpa si no es quien aquí lo consiente y no lo pone en un presidio o en China, pero no le de cuidado que ya se le está disponiendo la cama y yo haré que lo quiten de aquí y veremos a ver el redentor de los indios cómo se redime así mismo.

30 AGI, México, 498. Casafuerte al rey. México, 30 y 31 de diciembre de 1730. Ascensión Baeza Martín: El marqués de Casafuerte, virrey de Nueva España, 1722-1734. Tesis doctoral inédita. Sevilla, Facultad de Geografía e Historia de la Universidad de Sevilla, 2001, pp. 106-109. 
El mismo escribano atestiguaba que en su presencia se había dicho que el gobernador Arriaga había jurado que iba a matar a Villalobos de un trabucazo por haber escrito al rey en su contra en el asunto de la muerte de los indios de Nuevo León. ${ }^{31}$

\section{¿Desagravio o arreglo final?}

Ya hemos visto cómo las persistentes tentativas de Villalobos por recuperar la plaza fueron inútiles. Sus esfuerzos para que la Cámara de Indias le certificara el no haber percibido los sueldos de dicho empleo fracasaron igualmente. Se había marchado a Madrid, como ya se ha comentado, sin licencia del virrey porque decía que en México se le cerraron todas las puertas de la justicia, se le desterró 50 leguas y amenazó con presidio si presentaba más instancias. En Madrid estuvo durante cuatro años en los cuales explicaba que había padecido muchas penurias por haberse gastado todo su patrimonio en servicio del monarca, abandonando sus casas de México y Nuevo León para defender la causa de los indígenas. En compensación y atendiendo a sus méritos, pretendió sucesivamente los gobiernos de Puerto Rico, Isla Margarita, Nuevo León y Honduras, pero no se consideró oportuno incluirlo en la terna de cada uno que se presentaba al rey. ${ }^{32}$

Sin embargo, pasados once años, el asunto dio un giro. Teniendo en cuenta lo que Casafuerte expusiera en 1730 sobre que se le podría dar otro empleo excepto el de protector y valorando, así mismo, el Consejo que eran ciertas las muertes y ventas de indios durante el gobierno de Arriaga "y la inocencia de Villalobos", decretó en 18 de agosto de 1731 que acudiera a la Cámara de Indias, en donde se determinó que se le tuviere presente para alguna vacante de alcaldías mayores. A los pocos meses se le propuso en primer lugar para la de Texcoco. Finalmente, Felipe V, sobre consulta de la Cámara de 18 de noviembre de 1733, le confirió el corregimiento de Huamanga (Perú), plaza que había sido beneficiada antes e igualmente lo sería después de esta designación. de 1727.

31 AGI, Guadalajara, 173. Certificación de Juan Álvarez de la Plata. México, 2 de septiembre

32 AGI, Indiferente General, 144, N. 68. Relación de méritos y servicios del capitán Nicolás de Villalobos. Madrid, 16 de septiembre de 1729 y Memorial de Villalobos al rey (s/f). Ibidem. Nota de la Secretaría del Consejo (s/f). AGI, México, 567. Memorial de Villalobos al rey (s/f) y Extracto del Consejo. Madrid, 27 de junio de 1731. AGI, Guadalajara, 173. Memorial de Villalobos al rey México, 6 de mayo de 1727. Ibidem. Consejo, 17 de agosto de 1729. 
El 18 de marzo de 1734 se le despachó el título de corregidor de esa población peruana en el que, de forma casi idéntica a la que Villalobos había detallado en sus memoriales y certificaciones, el monarca hacía mención a lo bien que le había servido durante 26 años en distintos destinos y, curiosamente, en el de capitán protector general de indios del Nuevo Reino de León. La duración del nuevo cargo era por cinco años, con un sueldo anual de 2.000 pesos ensayados de a 450 maravedíes cada uno..$^{33}$

Para poder costear tan dilatado viaje y las deudas contraídas pidió que se le pagaran los sueldos que afirmaba que se le debían desde el 21 de febrero de 1720, en que Barbadillo le nombró protector, hasta el 18 de marzo de 1734 en que se le confirió el corregimiento de Huamanga en cantidad de 1.400 pesos anuales. La razón que daba era la de haberse ocupado todo ese tiempo en la solicitud y defensa de los indios.

Es perceptible que los emolumentos reclamados por Villalobos excedían a los que pudieran corresponderle, pues tanto en el nombramiento hecho por Barbadillo, que ya sabemos que se derogó, como en el del virrey Valero, que tampoco tuvo efecto, constaba que el sueldo asignado eran 700 pesos, sin los 350 de más que se le señalaron a su antecesor, Urrutia, por los dos escoltas y el tabaco y que en total sumaban 1050 pesos. Se evidencia, pues, que lo que hizo fue interpretar a su conveniencia ambos títulos. Si no hubiera sido así, no tenía por qué haber solicitado en 1720, como lo hizo, dos escoltas que, por otra parte, se le denegaron. No obstante, el Consejo ordenó al virrey en 1735 que se le oyera en justicia y se le pagara lo que legítimamente se le debiera. ${ }^{34}$

Villalobos hizo el juramento del puesto de corregidor en Madrid el $1 .^{\circ}$ de abril de 1734. Estando en Cádiz, se le dio despacho el 10 de mayo de 1735 para que se embarcara, junto con dos parientes y un criado, en uno de los dos navíos guardacostas. Poco más sabemos de este fugaz protector de indios, tan sólo que pretendió que se le honrara con el grado de coronel de

33 AGI, México, 567. Extracto del Consejo. Madrid, 27 de junio de 1731 y Nota del Consejo (s/f). AGI, Indiferente General, 145, N. 21. Relación de méritos y servicios del capitán de caballos Nicolás de Villalobos. Madrid, 3 de octubre de 1731. En esta relación constan los nombres de quienes certificaban sus servicios en España, en cambio, para avalar los efectuados en Nuevo León presentó en el Consejo el título de protector que le dio Valero el 9 de abril de 1720, cargo que el mismo virrey suprimió, al igual que más tarde lo haría el Consejo, amen de "otros instrumentos" sin que se detallen las firmas. AGI, Lima, 634. Título de corregidor de Huamanga a Nicolás de Villalobos. Buen Retiro, 18 de marzo de 1734.

34 AGI, Guadalajara, 118. Memorial de Villalobos al rey (s/f) y al Consejo, 5 de febrero de 1735. AGI, México, 498. Dictamen de la Cámara de Indias, 22 de agosto de 1731.Ver página 217 del presente artículo. 
caballería de los reales ejércitos "para su mayor autoridad y decencia del citado empleo". Se le respondió "no ha lugar". ${ }^{35}$

En mayo de 1736 se expidió título de ese corregimiento a Sebastián Cabrera "para sustituir al último previsto" en deferencia a sus méritos y a haber entregado 4.000 pesos de a 10 reales de plata en la Tesorería General. ${ }^{36}$

\section{Reflexión final}

El cargo de protector general de indios del Nuevo Reino de León no sólo era útil sino preciso en una etapa de la historia de esta provincia en la que se trataba de introducir unas reformas en la organización de la población indígena mediante la abolición de las congregas y el establecimiento y consolidación de los pueblos de indios. Así lo entendió Barbadillo, tanto en su condición de visitador como en la de gobernador, y fue apoyado por sus superiores. Su carácter efímero dependió más que de la falta de honradez y esmero del individuo que ocupaba ese destino — aspectos que naturalmente no hay que desestimar-, de las trabas que pusieron los gobernadores y demás grupos dominantes, ya civiles o eclesiásticos, y, a veces, del débil apoyo del gobierno virreinal, además de la burocratización y sus contradicciones, que tanto ralentizaban y complicaban la resolución de los negocios.

Los roces jurisdiccionales y las pasiones, afanes e intereses de cada colectividad impidieron que tal empleo se afianzara, máxime, con una costumbre tan arraigada en esa región fronteriza y alejada del gobierno central, como era la de utilizar el servicio de los indios con una nula o muy escasa remuneración e, incluso, conseguir ganancias con su venta. Por otra parte, muchos indígenas se habían habituado a obtener víveres y demás géneros por medio de los asaltos o de una fingida paz que prometían una y otra vez sin tener que someterse a la servidumbre de los pueblos. Este conjunto de circunstancias repercutían desfavorablemente en las relaciones de convivencia entre colonos e indios y en el sistema económico y laboral de la región. De igual forma, para los casi siempre consumidos fondos del Erario era un alivio suprimir costes.

Recibido el 22 de octubre de 2008 Aceptado el 15 de septiembre de 2009

35 AGI, Contratación, 5482A, N. 1, R. 19. Certificación de Antonio de Salazar. Madrid, 1. ${ }^{\circ}$ de abril de 1734 y Permiso de embarque. Cádiz, 10 de mayo de 1735. AGI, Lima, 489. Memorial de Villalobos al rey (s/f) y Minuta del Consejo, año 1735.

36 AGI, Lima, 634. Título de corregidor a Sebastián Cabrera. Aranjuez, 27 de mayo de 1736. 


\section{Bibliografía}

María Luz Alonso: "La visita de Garzarón a la Audiencia de México. Notas para su estudio", Estudios jurídicos en homenaje al maestro Guillermo Floris Margadant, México, Universidad Nacional Autónoma de México (UNAM), 1988.

Ascensión Baeza Martín: El marqués de Casafuerte, virrey de Nueva España, 1722-1734. Tesis doctoral inédita, Sevilla, Facultad de Geografía e Historia de la Universidad de Sevilla, 2001.

Constantino Bayle (SJ): "El protector de indios", Anuario de Estudios Americanos (AEA), II, Sevilla, 1945, pp. 1-180.

Woodrow Borah: El Juzgado General de Indios de la Nueva España, México, Fondo de Cultura Económica (FCE), 1985.

Paulino Castañeda Delgado: "La condición miserable del indio y sus privilegios", AEA, XXVIII, Sevilla, 1971, pp. 245-335.

Charles R. Cutter: The Protector de Indios in Colonial New Mexico 1569-1821, Albuquerque, University of New Mexico Press, 1986.

Juan Bautista Chapa: Historia del Nuevo Reino de León de 1650 a 1690, Monterrey, Gobierno del Estado de Nuevo León, 1990.

Diego de Encinas (recop.): Leyes de Indias. Cedulario de Encinas. Estudio e índices por Alfonso García Gallo, Madrid, Cultura Hispánica, 1990.

Eugenio del Hoyo: Historia del Nuevo Reino de León (1577-1723). Monterrey, Instituto Tecnológico y de Estudios Superiores, 1972, 2 vols.

Francisco de Icaza Dufour (coord.): Recopilación de Leyes de los Reynos de las Indias, México, Miguel Porrúa, 1987, 5 vols.

Alfredo Jiménez Núñez: El gran norte de México. Una frontera imperial en la Nueva España (1540-1820), Madrid, Tebar, 2006.

Alonso de León: Historia de Nuevo León con noticias sobre Coahuila, Tejas y Nuevo México, México, Librería de la Vda. de Ch. Bouret, 1909.

Andrés Montemayor Hernández: "La congrega o encomienda en el Nuevo Reino de León", Humanitas, 11, Monterrey, 1970, pp. 539-575.

Luis Navarro García: Don José de Gálvez y la Comandancia General de las Provincias Internas del Norte de Nueva España, Sevilla, Escuela de Estudios-Hispano-Americanos, 1964.

Patricia Osante: Orígenes del Nuevo Santander (1748-1772), México, UNAM, 1997.

Philip Wayne Powell: Capitan mestizo. Miguel Caldera y la frontera norteña. La pacificación de los chichimecas (1548-1597), México, FCE, 1980.

Beatriz Suñe Blanco: "Evolución de la figura del protector de indios en la frontera norte de Nueva España", en Antonio Gutiérrez Escudero y María Luisa 
Laviana Cuetos (coords.): Estudios sobre América, siglos XVI-XX, Sevilla, Asociación Española de Americanistas, 2005, pp. 727-744.

Carlos Manuel Valdés: La gente del mezquite. Los nómadas del noreste en la colonia. México, Centro de Investigaciones y Estudios Superiores en Antropología Social, 1995.

Silvio Zavala: Entradas, congregas y encomiendas de indios en el Nuevo Reino de León, Sevilla, Universidad de Sevilla, 1992. 